pyrrolidine diester II, b.p. $83^{\circ}-85^{\circ} / 0.5 \mathrm{~mm}, n_{D}^{25} 1 \cdot 4589, I . R$. $\left(\mathrm{CHCl}_{3}\right) 3 \cdot 0,5 \cdot 8$, and $11 \cdot 3 \mu$ (found: $\mathrm{C}, 57 \cdot 90 ; \mathrm{H}, 7 \cdot 64$; $\mathrm{N}, 6 \cdot 41$. $\mathrm{C}_{11} \mathrm{H}_{17} \mathrm{O}_{4} \mathrm{~N}$ requires $\mathrm{C}, 58 \cdot 13 ; \mathrm{H}, 7 \cdot 54 ; \mathrm{N}, 6 \cdot 16$ per cent). This product by alkaline hydrolysis and subsequent decarboxylation in $10^{-4} \mathbf{M}$ hydrochloric acid gave, in 65 per cent yield, the hydrochloride of $I$, which crystallized from ethanol othyl acetate in fine plates, m.p. $217^{\circ}-218^{\circ}$ decomp., I.R. ('Nujol') $11 \cdot 3 \mu$ (found: C, $44 \cdot 03 ; \mathrm{H}, 6 \cdot 13$; $\mathrm{N}, 8 \cdot 36 ; \mathrm{Cl}, 21 \cdot 43 . \mathrm{C}_{6} \mathrm{H}_{10} \mathrm{O}_{2} \mathrm{NCl}$ requires $\mathrm{C}, 44.05 ; \mathrm{H}$, $6.16 ; \mathrm{N}, 8.56 ; \mathrm{Cl}, 21.67$ per cent). Isolation of the free amino-acid was accomplished by treatment of the hydrochloride with a slight excess of silver carbonate. The resulting 4-methylene-DL-proline (I) crystallized from wet methanol-ethyl acetate in 85 per cent yield as fine. matted needles, m.p. $243^{\circ}-245^{\circ}$ decomp. (capillary, rapid heating), I.R. ('Nujol' or potassium bromide) $\mathrm{C}=\mathrm{CH}_{2}$ at $11 \cdot 3 \mu$, nuclear magnetic resonance $\left(\mathrm{D}_{2} \mathrm{O}\right.$, acetone reforence) $\mathrm{C}=\mathrm{CH}_{2}$ as a close quartet centred at $4.85 \tau$ (no methyl protons) (found: $\mathrm{C}, 56 \cdot 73 ; \mathrm{H}, 7 \cdot 30 ; \mathrm{N}$, 10.87. $\mathrm{C}_{6} \mathrm{H}_{9} \mathrm{O}_{2} \mathrm{~N}$ requires $\mathrm{C}, 56 \cdot 68 ; \mathrm{H}, 7 \cdot 14 ; \mathrm{N}, 11.02$ per cent).

Through the kindness of Dr. L. Fowden, University College, London, a sample of 4-methyleneproline isolated from loquat seeds ${ }^{2}$ was made available to us for comparison. In addition to having identical nuclear magnetic resonance spectra $\left(\mathrm{D}_{2} \mathrm{O}\right)$ and indistinguishable paper chromatographic behaviour ${ }^{2}$, the natural and synthetic substances had completely superposable infra-red spectra ('Nujol' and potassium bromide), identical crystallization characteristies, and undeprossed mixed melting point $\left(242^{\circ}-245^{\circ}\right.$ decomp.), and also gave a common product on catalytic hydrogenation (mainly cis-4-methyl-DL-prolino ${ }^{1,2}$, m.p. $233^{\circ}-235^{\circ}$ decomp.), thereby directly confirming not only the structure but also the racemic character of the natural amino-acid.

We thank Prof. G. W. Kenner and Dr. R. J. Abraham of the University of Liverpool for the nuclear magnetic resonance spectral identification of cis-4-methyl-DLproline. This work was supported by the U.S. National Science Foundation and the Alfred P. Sloan Foundation. Some of the initial phases of this work were conducted under a research grant from the U.S. National Institutes of Health.

Albert W. Burgstahler Michael L. Trollope Charles E. A.man

Department of Chemistry,

University of Kansas, Lawrenee.

' Bethell, M., Kenner, G. W., and Shepperd, R. C., Nature, 194, 864

${ }^{2}$ Gray, D. O., and Fowden, L., Nature, 193, 1285 (1962).

"Wailes, P., Whiting, M. C., and Fowden, L., Nature, 174, 130 (1954).

- Done, J., and Fowden, L., Biochem. J., 51, 451 (1952). Zacharius, 1961 (1954). Harris, G., Chem. and Indust., 244 (1954).

- Mooradian A and Cloke, J. B. J. Amer. Chem. Soc., 67, 942 (1945) Cf. Burgstahler, A. W., and Aiman, C. E., Chem. and Indust., $1430^{\circ}$ (1962).

\section{Electron Spin Resonance Spectrum of Irradiated Cellulose II}

AN asymmetric electron spin resonance spectrum has usually been reported for the free radicals produced by the $\gamma$-irradiation of cellulose ${ }^{1,2}$. During the course of an investigation on tho effect of crystallinity and cross-linking on the degradation of cellulose by $\gamma$-radiation we noticed that while specimens of ramie and cotton (cellulose I) gave the familiar asymmetric electron spin resonance spectrum (Fig. 1B), all the samples of regenerated cellulose (cellulose II) gave the more symmetric pattern (Fig. 1 $A$ ).

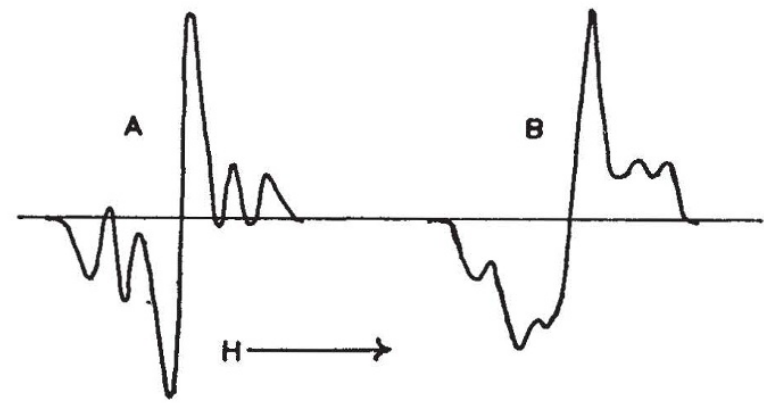

Fig. 1. Differential plot of the electron spin resonance spectra of cellulose specimens several weeks after receiving a 10-megarad dose of

While the cause of this difference has not been further investigated, its relationship to the differences in the X-ray fibre diagram ${ }^{3}$ is of interest. Wo have recently shown from the relationship between the radical concentration and tho dogreo of erystallinity that the stable radicals in cellulose are in the ordered regions. It follows that the differences in electron spin resonance pattern reported here must be a reflexion of the differences in molecular arrangement in cellulose I and cellulose II crystallites and might be expected to yield further information about these structures.

We thank Dr. Roberts, of the Atomic Energy Research Establishment, Wantage, who arranged for the irradiation of our specimens.

Department of Chemistry,

$$
\text { G. S. PARK }
$$

Welsh College of Advanced Technology. Cardiff.

$$
\text { J. C. WARD }
$$

C.S.I.R.O.

Division of Coal Research, P.O. Box 175,

Chatswood,

Now South Wales, Australia.

${ }^{1}$ Abraham, R. J., and Whiffen, D. H., Trans, Farad. Soc., 54, 1291 (1958). ${ }^{2}$ Florin, R. E., and Wall, L. A., J. Polymer Sci., A, 1, 1163 (1963).

${ }^{3}$ Howsman, J. A., and Sisson, W. A., in Cellulose, edit. by Ott, E., and Spurlin, H. A., 239 (Interscience, New York, 1954).

\section{Crystal and Molecular Structure of Glaucarubin}

Glaudarubin, a bitter lactone found in Simaruba glauca, and used medicinally as an amœbicide, has the ompirical formula $\mathrm{C}_{25} \mathrm{H}_{36} \mathrm{O}_{10}$ and a molocular weight of 496 . Its chemical structure is known to be similar to that of chaparrin ${ }^{2}$ and quassin ${ }^{3}$. Recently the chemistry of the family Simaroubaceae has been the subject of a consider. able number of investigations ${ }^{4,5}$. Examination of the structure of this compound had been in progress in the Department of Medicinal Chemistry, State University of Now York at Buffalo, when it was decided to apply X-ray crystallographic methods to this problem. The crystals of $p$-bromobenzoate derivative wero prepared at this department and the $\mathrm{X}$-ray investigations were undertaken at the Roswell Park Memorial Institute at Buffalo, with the hope that a complete single erystal structural study of this compound would contribute useful information about the chemistry of this class of compounds.

The crystal structure of $p$-bromobenzoyl derivative has now been solved from three-dimensional X-ray diffraction data collected on a Goneral Electric XRD 5 single crystal diffractometer oquipped with a goniostat. It was found that this compound crystallizes in the monoclinic system and belongs to the space group $P 2_{1}$. The cell contains two molecules and has dimensions ths follows:

$$
a=13.79 \AA \quad b=6.99 \AA \quad c=17.35 \AA \quad \beta=110.8^{\circ}
$$

